\title{
Bakım Etiği Penceresinden Kadın Yoksulluğu
}

\section{Female Poverty in the Context of Care Ethics}

\author{
Emine Elif Ayhan' 1 (1)
}

\section{Öz}

Bakım; yaşlılık, hastalık, engellilikveya diğer koşullar nedeniyle günlük yaşam aktivitelerini yerine getiremeyen kişilere yönelik desteği ifade eden ve toplumsal düzeni korumayı içeren çok yönlü bir kavramdır. Bakımın sağlanmasına yönelik sosyal sorumluluk, kamusal alanlardan ziyade hane içinde karşılanması gereken bir yükümlülük olarak görülmektedir. Hane içindeki güçilişkilerinin cinsiyete dayalı doğası göz önüne alındığında, bakımın sağlanması nihai olarak kadınların mesuliyetindedir. Geleneksel bir anlayışla kadınlara yüklenen bakım görevleri, pek çok açıdan kadınları yoksullaştırmaktadır. Bu tür bir yoksulluk çeşidi ile mücadele etmek için bazı politikalar uygulanmasına rağmen kadınların ücretsiz bakım işinde hala erkeklerden daha fazla zaman harcadıkları ortadadır. Bakım işindeki bu "kadınsal doğa", etik bakım anlayışını doğurmuştur. Etik bakım, bakım hizmeti verme ve alma konusunda insan ilişkilerinin ve ihtiyaçlarının ana unsurlarında ahlaki bir önem olduğunu ima eder. Sosyal ilişkiler ağı içinde bakım verenler ile bakım alanların refahını uyumlaştırarak aralarındaki ilişkileri sürdürmeye odaklanan etik bakım, bir anlamda insan ilişkilerinin yeni bir okumasını sağlayan bir yaklaşım türüdür. Bu çalışma sosyal bakım ve bakım etiği kavramları ile ilgili çalışmaları içermekte, bakımın doğası hakkında kavramsal ve ahlaki tartışmalara katkıda bulunmakta ve bakım hizmetlerini özel veya kişisel ilişkilerin ve cinsiyetçi yaklaşımların ötesinde ele alarak küresel bir bakım etiğinin inşa edilmesi gerektiğini savunmaktadır.

\section{Anahtar Kelimeler}

Bakım, Sosyal bakım, Etik bakım, Kadın yoksulluğu, Üçüncü vardiya

\begin{abstract}
Care is a multi-pronged concept that expresses support for people who cannot fulfill their daily living activities owing to old age, illness, disability, or other conditions; this includes maintaining the social order. Social responsibility for the provision of care is seen as an obligation that must be met within the household rather than in public spaces. Given the gendered nature of power relationships within the household, the provision of care ultimately becomes the responsibility of women. Caring duties imposed on women with a traditional understanding impoverish women in many ways. Despite some policies being implemented to
\end{abstract}

1 Sorumlu Yazar: Emine Elif Ayhan (Doktora Adayı), Kocaeli Üniversitesi, Çalışma Ekonomisi ve Endüstri İlişkileri Anabilim Dalı, Yoksulluk Çalışmaları DP, Kocaeli, Türkiye. E-posta: elifayhan93@gmail.com ORCID: 0000-0001-6692-0633

Atıf: Ayhan, E. E. (2022). Bakım Etiği Penceresinden Kadın Yoksulluğu. Journal of Social Policy Conferences, 82, Advanced online publication. https://doi.org/10.26650/jspc.2022.82.1007390 
combat this type of poverty, women clearly still spend more time performing unpaid care work compared to men. This "feminine nature" in the care business has brought forth an understanding of ethical care. The ethics of care implies a moral importance in the core elements of human relationships and needs in giving and receiving care. Such ethics, which focus on maintaining the relationships between caregivers and care recipients by harmonizing the welfare of caregivers within the social network, comprise an approach that provides a new reading of human relations. The present investigation examines studies on the concepts of social care and care ethics and contributes to the conceptual and moral discussions on the nature of care, arguing that global care ethics should be built by considering care services beyond private or personal relationships and sexist approaches.

\section{Keywords}

Care, Social care, Ethics of care (care ethics), Female poverty 


\section{Extended Summary}

When a person encounter difficulties in performing activities of daily living (ADLs) independently owing to a congenital or later decline in their skills or functional status, they have to receive care service. Performing ADLs is an indispensable necessity for an individual to continue their life. Thus, care services are of vital importance for people facing difficulties in carrying out their daily life activities. However, care work is not only limited to protecting and taking care of one's body but also has a nature that nurtures social relations and protects the social order. Because people first experience care in the family environment, it is quite reasonable to perceive domestic and family-based care as the foundation of all care relationships. Nonetheless, this situation limits care work to the female members of the family, their private lives, and their close relationships. Therefore, this results in the exclusion and marginalization of women from the spheres of social existence and value. In addition, caretaking becomes an undesirable activity while caregiving is seen as a worthless occupation; the social status of the parties to the care and care work is consequently considered worthless. However, care work is not a gender-specific and private-life activity. Beyond these established borders for care, a concept of care ethics has emerged with which the unique nature of care can be understood.

The ethics of care is a concept that has developed in last 40 years and questions the place of care in society and moral life. These ethics elevate care services to an important value in human life. The starting point of care ethics is any formal and informal care work practice that is important to individual well-being but is not given the value it deserves. People face moral, political, technical, and psychological questions when engaged in daily care activities. Therefore, care work requires knowledge and judgment capability. Such inquiries add a moral edge to care work. Accordingly, caring for someone in terms of care ethics is considered a vital activity for all kinds of living together. Carol Gilligan formulated her ethics of care while attempting to address the problems that she saw in Lawrence Kohlberg's moral psychology. Gilligan often discusses the expression of women's responsibilities in caregiving and highlights that social structure, rather than any natural feature of femininity, causes the prevalence of women in caregiving positions. However, because the ethics of care define care generally as meeting human needs in a moral order, it is argued that these ethics should be considered largely independent 
of gender. Nevertheless, women are frequently the subject of studies on care because of their disadvantageous position in the distribution of paid and unpaid care work. Given this context, the present study discusses the occurrence of female poverty based on care ethics.

It is expected that women alone will fill the gap left by the public and private sectors in unpaid care work. In fact, women are pushed toward multidimensional poverty as they miss economic and social opportunities owing to the unpaid care work that they traditionally undertake. Therefore, it can be argued that unpaid care work impoverishes women. This study draws attention to the importance of building a global care ethic with an ethical care approach by eliminating the gender inequality factor that characterizes care work as the responsibility of women. The ethics of care propose a consideration of care practices in a moral framework; as this challenges historically constructed gender norms, roles, and power relations, this framework can be considered a strategy to combat female poverty based on care work. To this end, care services should be integrated with global social policy by emphasizing the moral philosophy of care ethics. The ethics of care provide the world with a school of thought that sheds new light on care and offers possible solutions. 


\section{Bakım Etiği Penceresinden Kadın Yoksulluğu}

Bakım işinde, evrensel kurallara ve bunların ima ettiği hak ve ödevlere oldukça az yer verilir. Çünkü bakım hizmeti verilirken bakım hizmeti alan kişinin özelliklerine odaklanılır, onun ihtiyaçlarının karşılanması esas alınır. Bakım hizmeti vermek için evrensel ilkelerin geçerliliğine güvenmek yerine kişinin; empati, sempati, yardımseverlik ve sevgi duyguları genellikle bakım işinin daha faydalı ifa edilmesini sağlar (Held, 2015, s. 20). İnsanlar doğal olarak ilişkisel ve duyarlı varlıklardır. İnsanların birbiriyle bağlantılı olması ve karşılıklı bağımlılıkları öncülüğünde etik bakım veya bakım etiği anlayışı doğar.

Bakım etiği, tüm insanların ihtiyaç duyduğu, başkalarına ilgi ve özen gösterdiği gerçeğinden başlayan; kişisel, sosyal, ahlaki ve politik bir yaklaşımdır. İnsanlar arasında var olan bakım ağı, insanları birbirine bağlayan ilişkileri kapsamaktadır. Çünkü yaşamı boyunca her insan -ihtiyaçları değişse bile- her zaman ve her koşulda bakım hizmeti vermekte ve almaktadır. Bakım etiği kavramı, hem kendine hem de başkalarına sağladığı bakım faaliyetlerine, ahlaki değerleri dahil edecek şekilde geniş bir düşünme biçimi sağlayan yegâne bir yaklaşımdır. Bakım eğiti yaklaşımı, dünya çapındaki tüm insanlara adil ve hakkaniyetli muamele göstermeyi ve bu tür bir muamelenin; bütünsel, bağlamsal ve ihtiyaç merkezli doğasını, bakım uygulamalarıyla muhafaza etmeyi esas almaktadır.

Kişilerin, kendisinin ve ailesinin günlük yaşamsal aktivitelerini yerine getirmek için yaptıkları faaliyetleri, bir anlamda ekonomik ve sosyal statüsü ile kişisel ve ailesel faktörlere bağlıdır. Bu faaliyetler; yemek pişirmek, temizlik yapmak, çocuk yetiştirmek, yaşlı akrabalara bakmak, alışveriş yapmak ve diğer ev işlerini içerebilir. Tabii ki bu işılerin tamamı kadınlar tarafından yapılmamaktadır ancak küresel olarak kadınlar, hem hane içinde hem toplumda, her gün ücretsiz bakım ve ev işlerinin \% 75 'inden sorumlu olduğu iddia edilmektedir (Moreira da Silva, 2019). Kadının görev ve sorumluluğunda tensip edilen bakım işine farklı bir boyut getiren bakım etiği, bakımın ihmal edilen değerlerini yansıtırken bakım sorumluluklarını ve uygulamalarını ahlakın özü olarak kabul eder ve kadınların düşük değer verilen bakım pozisyonlarında yaygınlığının, kadınlığın doğal bir özelliğinden ziyade sosyal yapının neden olduğunu savunur.

Bu çalışmada bakım emeğini, kadınların sorumluğu olarak işaret eden toplumsal cinsiyet eşitsizliği faktörü görünümünden kurtararak tüm dünyada etik bakım yaklaşımıyla, küresel bir bakım etiği inşa etmek gibi zorlu bir göreve hemen 
başlanması gerektiği öne sürülmektedir. Bunun için ilk bölümde kapsamlı bir sosyal bakım anlayışı hakkında açıklamalar yapılmış, ikinci bölümde, etik bakım yaklaşımının ortaya çıkışı ve temel savunucularının görüşlerine yer verilerek, etik bakım yaklaşımı derinlemesine anlamlandırılmıştır. Çalışmanın üçüncü bölümü ise neredeyse tüm toplumlarda kadınlara atfedilen bakım sorumluluklarının hâlen devam ettiği son verilerle ortaya konulmuş ve bu durumun da kadınları yoksullaştırdığına dair çıkarımlarda bulunularak, çalışmanın sonuç bölümünde bakım etiği yaklaşımını benimsemenin önemi vurgulanmıştır.

\section{Kapsamlı Bir Sosyal Bakım Anlayışı}

Bakım kavramı; emek vermeyi, tutumu ve erdemi içinde barındırır. Emek vermek olarak bakım, kişinin kendisini ve ihtiyaç halinde başkalarını önemseme işidir. Bir tutum olarak bakım, duygusal bir bağ kurabilmek ve bir başkasına iyilik yapabilmek anlamına gelir. Emek vermek, tutum olmadan yapılabilir ancak bakım verme tutumu olmadan verilen bakım emeği ile bir başkasının ne istediğini anlamak mümkün değildir ve böyle bir bakım hizmeti yalnızca belli kalıplar dahilinde verilmiş olacaktır. Bu nedenle bakım tutumunun eşlik etmediği bakım emeği, aslında iyi bir bakım olmayacaktır. Bir erdem olarak bakım ise kişinin bakıma muhtaç birine karşı gerçekleştirdiği bakım davranışındaki eğilimdir. Karşılıklı sevgi ilişkileri, bakım vermeyi kolaylaştırır, ancak eğilim, yakınlara olduğu kadar yabancılara da yönlendirildiğinde bakım işinin de daha kapsayıcı ve faydalı olacağı açıtır (Kittay, 2011, s. 52-53). Hugman (1991, 5-6)'a göre bakımın ikili bir anlamı vardır. Bakım hem zihinsel bir dikkat eğilimine hem de bu eğilimin sonucu olarak meydana gelen fiili uygulamalar olarak değerlendirilir. Örneğin, doktorun hastasına yönelik verdiği bakım hizmeti, öncelikle bir dikkat eğilimidir. Ardından bu dikkat eğilimi sonucu tıbbi tedavi reçetesine bağlı somut uygulamalar ortaya çıkar. Böylece insanın doğumundan ölümüne kadar hayatında bir yeri olan bakım olgusu, sağlık ve sosyal bakım olarak ikiye ayrılabilir. Sağlık bakımı kavramı; hastalığı, yarası veya sakatlığı olan birinin tedavisini kapsarken, sosyal bakım; beslenme, yıkanma, giyinme, hareket etme, korunma, çevresiyle iletişim kurma gibi günlük yaşam aktivitelerinde yardıma ihtiyaç duyan kişilere verilecek hizmetleri ifade eden kavramdir.

Birden fazla grubun birbirinden farklı ihtiyaçlarıyla ilgili olduğundan, kavramsal bir düzeyde sistematik bir sosyal bakım tanımı yapmak oldukça zordur. En genel haliyle sosyal bakım, belirli ihtiyaçları olan kişiler ve gruplar 
için bakım ve destek hizmetlerinin planlanması ve sunulmasıdır. Sosyal bakım için bu tanım oldukça üstünkörü gibi görünebilir ancak içinde anahtar kavramlar bulundurmaktadır. Tanımı üstünkörülükten kurtarmak adına içerisindeki temel kavramlara aşağıda yer verilecektir (Lalor \& Share, 2009, s. 4).

- Belirlenmiş ihtiyaçlar: Sosyal bakım alıcılarının gereksinimlerini, kısıtlamalarını, motivasyonlarını ve acı noktalarını keşfetme sürecidir. Bakım hizmetlerinin alıcıya katacağı değeri anlamak için kullanılmaktadır.

- Bireyler ve gruplar: Sosyal bakım bire bir olarak bireye de sağlanabilir, küçük veya büyük bir grup veya toplulukla çalışmayı da içerebilir.

- Bakım ve destek hizmetleri: Sosyal bakım, herkese kaliteli bakım verilmesi ve ayrıca diğer desteklerin sağlanması ile ilgilidir. Örneğin, günlük yaşam aktivitelerini yerine getiremeyen bir kişinin hayatını kolaylaştırmaya yönelik uygulamaları kapsar.

- Hizmetlerin planlaması ve sunumu: Sosyal bakım sadece ihtiyaçları karşılamak ile ilgili değildir, aynı zamanda bunları tasarlamak, planlamak ve uygulamakla da ilgilidir. Bu süreç, çeşitli istekler, beceriler ve anlayış türleri gerektirir. Örneğin, insanlara uygulamalı bakım ve destek sağlama isteği, insanların neye ihtiyacı olduğunu belirleme becerisi ve buna göre plan yapma yeteneği, tercihen mevcut kanıtlara ve politika rehberliğine dayanarak ve insanlarla doğrudan doğruya gerçek bir iletişim kurma anlayışıdır.

Bakımın çok yönlü yapısını anlamlandırmak üzere Fisher ve Tronto (1990, 40), anlaşılabilir bir sosyal bakım tanımını sunmuşlardır. Onlara göre en genel düzeyde sosyal bir açıdan bakım, olabildiğince refah düzeyi yüksek bir yaşam için dünyayı; korumak, sürdürülebilirliğini sağlamak ve onarmak üzere yapılan tüm faaliyetleri içeren bir tür etkinliğidir. Çünkü dünya, yaşamı sürdüren bir ağda iç içe geçmeye çalışan kişileri, özleri ve toplumları içermektedir. Bakımın çok boyutlu yapısına göre neredeyse tüm insan uygulamaları bazı bakım unsurlarını içerebilir. Bu nedenle sosyal bakım, sınırları olmayan ve her an her yerde var olan bir kavram olarak düşünülebilir.

Sosyal bir anlayışla ele alınan bakım, çeşitli yönlerden dikkate değerdir. Bu yönlerden biri, insanların birbirine verdiği değeri ortaya çıkarmasıdır. Diğeri, sadece ilkeler ve kurallar dizisiyle çevrili bir alandan ziyade esnek bir uygulama 
alanına sahip olmasıdır. Ayrıca bakım uygulamasında yer alan kişilerin; yaşam tarzlarına, koşullarına ve değerlerine göre bakım hizmetlerinin yeterliliği değiştiği için eşitlikten ziyade adaletli olmak önem kazanmaktadır. Bunlara ek olarak bakım, çeşitli kurum ve ortamlarda meydana gelebilen bir süreç olduğu için sosyal boyutuyla çevrelenmesi oldukça önemlidir.

Fisher ve Tronto (1990), sosyal bakım süreci için önce dört aşama tanımlamışlardır. Daha sonra Tronto (2013) bakım aşamalarına beşincisini eklemiştir. Bakım aşamaları, kapsamlı bir bakımın nasıl olabileceğine dair bir resim ortaya koyarak bakım alıcıları ve bakım vermeyi üstlenenlerin entegre olduğu bütünsel bir süreci fark etmeyi sağlar. Buna göre bakım aşamaları:

- Önemsemek (care about): Bakım ihtiyacının farkında olmayı ve bu ihtiyaca dikkat etmeyi içerir.

- Bakım Organizasyonu (caring for): Gerekli kaynakların ve personelin organize edilmesi, sıralanması ve belirlenen ihtiyaçları karşılayacak bakım işi için ödeme yapılma sorumluluğunun düzenlenmesini içerir.

- Bakım hizmeti vermek: Bakım hizmeti verme görevini üstlenmiş bireylerin ve kuruluşların gerekli bakım görevlerini fiziksel olarak karşılamasıyla ilgilidir.

- Bakım hizmeti almak: bakım ihtiyacı olan kişiye bakım hizmeti sağlanması ve sağlanan bakım hizmetinin değerlendirilme aşamasıdır.

- Illgilenmek (caring with): Bakım, insan ihtiyaçlarını karşılamayı sürdürebilmek için devam eden bir bakım döngüsüne güvenebildiğinde gerçekleşir. Bu tür kalıplar yerleşik hale geldiğinde güven ve dayanışma erdemlerini üretirler.

İyi bir bakım hizmetinin unsurlarını araştıran Amerikalı siyaset bilimci Tronto (2010, 161), sosyal bakımın iki tehlikeyle karşı karşıya olduğu görüşündedir. Bunlar, dar görüşlülük (parokializm) ve paternalizmdir. Küresel bir endişe olarak da değerlendirilebilen bakımla ilgili bu iki tehlike, daha somut bakım ilişkileri düzeyine indirildiğinde aslında güç sorunlarından ibaret olduğu anlaşılabilir. Dar görüşlülük, bakım ilişkilerinin aileler veya sosyal gruplar gibi dar çevrelerde gerçekleşmesini ifade etmektedir. Paternalizm, bakım verenlerin, çoğu zaman bakım alanlar üzerinde güç sahibi olması nedeniyle, bakım 
gerektiren herhangi bir durumda kendi yargılarını, bakım alanlar üzerinde uyguladıkları yollara atıfta bulunur. Bu nedenle bakım kavramının ahlaki bir yaklaşımla ele alınması zorunluluktur. Eğer ahlaki sınırlarla çevrelenmiş bakım olgusu, mevcut konumundan koparılıp insan yaşamının merkezine taşınırsa dünyanın şu anda görüldüğünden, olumlu yönde, farklı görüneceği açıktır.

Sosyal bakım hem ihtiyaçların rasyonel açıklamalarını hem de duyguların sempatik takdirini içerir. Gerek kavram gerek uygulama olarak bakım hizmetlerinin, sosyal ve politik bağlamda ahlaki çelişkileri, belirsizliği ve karmaşıklığı yansıttı̆̆ iddia edilebilir (Nguyen, Zavoretti, \& Tronto, 2017, s. 200). Bakımın belirsiz ve karmaşık doğası, özellikle kadınların daha fazla sorumluluk yüklenmelerine sebep olmuştur. Oysa bakım, kadın emeğinin geleneksel rolüyle, sosyal yardım kurumlarıyla veya ulus ötesinden işe alınan bakım hizmetlileri ile sınırlı değildir.

\section{Bakım Kavramına Feminist Bir Yaklaşım: Bakım Etiği}

Bakım hizmetleri özel yaşamı ilgilendiren ekstra işler olarak kabul edildiğinden kadınlara yüklenmiş, samimi ilişkilerle daraltılmış, bakıma muhtaç olma hali istenilmeyen bir durum olarak kabul edilmiş ve bakım verme işi de bunlardan ötürü değersiz bir iş olarak toplumda yerini almıştır. Oysa İnsanların günlük bakım faaliyetleri içinde; ahlaki, siyasi, teknik ve psikolojik yargılarda bulunmaları gerekir. O halde bakım faaliyeti ne basittir ne önemsizdir ne de bayağıdır; teknik bilgi ve muhakeme yeteneği gerektirir. Bu nedenle insanlara sunulacak kapsamlı bir sosyal bakım anlayışı için hem bakım hizmeti alanlara hem de verenlere fayda sağlamaya yönelik bir bakım anlayışına ihtiyaç duyulmaktadır.

Etik, ahlaki davranışların disiplinli ve sistematik bir yansıması olarak değerlendirilebilen; yargıları, sorumlulukları, amaçları ve eylemleri eleştirel bir bakış açısıyla görebilmenin bir yoludur. Ayrıca insanları birbirine bağlayan ilişkileri değerlendirmeye izin veren, insani yanlışları ortaya çıkarmaya yardımcı olan ve onları düzeltmenin yollarını öneren, bir anlamda toplumdaki refahı sağlamaya yönelik “olması gerekenler” ile ilgili bir kavramdır (Holstein, 2010, s. 630). Bakım kavramı, etik kavram ile harmanlandığında daha eksiksiz bir bakım doğası gün yüzüne çıkar. Bu bakış açısı rutinleşmiş günlük yaşamda; herkese söz hakkı vermeyi, istekleri karşılamayı ve ahlaki duyarlılıkları artırmayı kazandırma gayesindedir. 
Bakım etiğinin ayrı bir ahlaki teori olarak ortaya çıkışı, genellikle 1980'lerin ortalarında psikolog Carol Gilligan ve filozof Nel Noddings'in çalışmalarına atfedilir. Bu araştırmacıların her ikisi de geleneksel ahlaki yaklaşımların ataerkil toplum düzeni ile uyumlu olduğunu iddia etmişler ve feminist düşüncenin, ahlaki yaklaşımların merkezinde yer alması gerektiğini savunmuşlardır. Daha sonra Annette Baier, Virginia Held, Eva Feder Kittay, Sara Ruddick, Joan C. Tronto, Selma Sevenhuijsen, Fiona Robinson ve Frans Vosman gibi isimler, çalışmalarıyla bakım etiği kavramının gelişmesine katkıda bulunmuşlardır.

Carol Gilligan, öğrencisi olduğu Lawrence Kohlberg'in ahlaki gelişim kuramında (Theory of Moral Development) gördügü sorunları ele almaya çalıştığı noktada bakım etiğini tasarladı. Bu nedenle Carol Gilligan'ın “In a Different Voice: Psychological Theory and Women's Development (1982)" kitabı, bakım etiğinin doğuşu ile ilişkilendirilir. Kohlberg'in ahlaki gelişim kuramına göre, sosyal ilişkilerin doğasını anlamak için bireylerin bilişsel yetenekleri derinleştikçe, ahlaki olarak gelişim sürecine girerler (Kohlberg, 1968). Kohlberg, ahlaki gelişim sürecinin, hiyerarşik olarak düzenlenmiş aşamalardan geçtiğini iddia etmiştir ${ }^{1}$. Bu aşamalarda, kadınların genellikle erkeklerden daha düşük ahlaki gelişim aşamalarında olduklarına dair bulgular, Gilligan'1 rahatsız etmiştir. Gilligan, bu bulgular ile cinsiyet yanlılığı açısından Kohlberg'in çalışmalarını incelemiştir. Bu incelemeler, Kohlberg' in teorisinin yeterliliğini sorgulamanın yanı sıra toplumdaki ve ahlaki yaşamdaki bakımın yerini de sorgulayan incelemelerdir (Tronto, 1987, s. 645-647).

Gilligan, bakım etiğinde, Kohlberg'in adalet etiğinden ayıran üç temel özellik tanımlamıştır. Birincisi, bakım etiği, adalet etiğindeki kavramlar olan haklar ve kurallardan ziyade sorumluluk ve ilişkiler etrafında konumlanır. İkincisi, bakım etiği, biçimsel ve soyut olmaktan ziyade somut koşullara bağlıdır. Üçüncüsü ise bakım etiği bir dizi ilke olarak değil, bakım verme etkinliği olarak ifade edilir. Gilligan'a göre bakım etiği gerçek insanların günlük yaşamlarındaki deneyimlerine ve ahlaki sorunlarına dayalıdır (Gilligan, 1993, s. 20). Bu arka planda, Gilligan'ın bakım kavramını, bakımın karakteristik özelliklerini dikkate alarak genişlettiği görülmektedir. Bakım etiğinin doğuş hikayesini esas alarak Gilligan'a (1993) göre bakım etiği, karmaşık ve soyut ilkelerden ziyade, belirli

1 Lawrence Kohlberg'in ahlaki gelişim kuramına ilişkin daha kapsamlı okumalar için bakınız; Kohlberg, L. ve Hersh, Richard H. 1977. "Moral Development: A Review of the Theory". Theory Into Practice, 16(2): 53-59. doi:10.1080/00405847709542675

Kohlberg, Lawrence. 1973. "Stages and Aging in Moral Development-Some Speculations" The Gerontologist, 13(4): 497-502. https://doi.org/10.1093/geront/13.4.497 
bağlamlarda başkalarının ihtiyaçlarını karşılama ve karşılıklı ilişkileri sürdürme eylemidir (s. 28).

Bakım etiği perspektifi, Kantçı deontoloji² ve adalet teorisi gibi ahlaki eylemleri vurgulamak için ilkelere dayanan etik teorilerle taban tabana zıt olduğu söylenebilir (Burton \& Dunn, 2013). Çünkü Bakım etiği, kişilerin birbirine bağımlı, sosyal olarak yerleşik bir varlık olarak anlaşılmasıyla karakterizedir. Böyle bir anlayış, insanların başkalarıyla mesafeli bir şekilde ilişki kuran, bağımsız özneler olduğuna ilişkin geleneksel etik teorilerine aykırıdır. Aynı zamanda ahlaki karar vermenin doğası hakkındaki geleneksel görüşlere de aykırıdır. Çünkü geleneksel etik teoriler, ahlaki kararları, nesnel ve tarafsız olarak vermeyi talep etmektedir. Geleneksel görüşlere göre, insanlar muhakeme kapasitesini kullanmalı, bağımsız ve rasyonel failler olarak ahlaki kararları nesnel düşüncelere dayalı olarak vermelidir. Ancak feminist etik savunucuları, bakım konusunda, nesnellik, tarafsızlık ve bağımsızlığa yapılan vurguyu sorgularlar. İnsanın birinci dereceden ailesinden, arkadaşlarına, hayatındaki önemli kişilere, meslektaşlarına vb. kişilere kadar geniş bir ilişkiler ağının içine doğduğunu iddia ederler. Bu durumda insanın sosyal çevresi, geleneksel açıklamaların öne sürdüğü bağımsız ve nesnel varlıklar olmadığı anlamına gelir. İnsanlar, duygusal ve fizyolojik destek için birbirine ihtiyaç duyan, birbirine bağımlı varlıklardır (Parks, 2003, s. 54-55).

Bakım etiğinin en önemli savunucularından Nel Noddings'e göre kişi sadece kendini önemsediğinde iyi olma halinde eksiklik meydana gelir. Bu durumda iyi olma hali, bakım durumunun bir değerlendirmesidir. İnsanlar birbirine ihtiyaç duyduğu ve yardım ettiği zaman, aslında etik benliklerine de en yakın oldukları zamandır. Etik benlik, gerçek benlik ile bakım ve özen gösterilen ideal benlik arasındaki aktif bir bağdır. Kişiyi doğal olarak diğerine bağlayan şey, kişiyi başkası aracılığıyla kendine yeniden bağlar düşüncesiyle karşılıklı ilişkinin temel kabulünden doğar. Kişi bu hayatta doğal olarak yalnız değildir

2 Kantçı etik, doğru ve yanlış olarak tanımlanan görevlere odaklanmaktadır. Doğru ve yanlış, doğrudan eylemleri öngördükleri için iyi ve kötüden (değer yargıları) farklıdır. Doğru eylemler, yapılması gerekenler (ahlaki olarak sakıncası olmayan eylemler) ve yanlış eylemler, yapılmaması gerekenlerdir (ahlaki olarak sakıncalı eylemler). Bu etik tarzına deontoloji denir. Yunanca deon kelimesinden türetilen deontoloji, görev veya yükümlülük anlamına gelir. Deontolojide, deontik kategoriler birincildir, değer yargıları ise deontik kategorilerden türetilir. Kant, ahlakın rasyonel olması gerektiğine inanmakta ve insanlar arasındaki tüm görevlerin kategorik buyruktan türetilebileceğine savunmaktadır. Kant’a göre kategorik buyruk; ahlaki bir zorunluluğun isteklere, arzulara veya ihtiyaçlara bağlı olmamasıdır. Kategorik buyruklara örnek olarak "İhtiyacı olanlara yardım etmelisin" verilebilir. Kantçı deontoloji, isteklerin veya hedeflerin ne olduğunu önemsemez ancak ne olursa olsun kategorik bir buyruğu izlemeyi kasteder (Kranak, 2019, s. 52-53). 
ve bir başkasına özen gösterme dürtüsünü yok saydığında aslında kendisinden koptuğu bir yalnızlığa sürüklenir ve doğal olarak ilişkilerini yeniden kurmaya çalışır. Buradan yola çıkarak akımın evrensel bir insan özelliği olduğunu öne süren Noddings, bir bakım ilişkisindeki insanlar için etik yaklaşımın temel olduğunu ileri sürmektedir (Noddings, 2013, s. 49-51).

Amerikalı siyaset bilimci Joan C. Tronto'nun “Moral Boundaries" (1993) adlı kitabında, bakım etiği için kapsamlı bir tanım bulunmaktadır. Ona göre bakım, etik bir kavram olarak ele alındığında, sahip olduğu bazı özellikler ortaya çıkmaktadır. Öncelikle bakım, yalnızca insanların etkileşimi ile sınırlı değildir. Başka insanlara olduğu kadar nesnelere ve çevreye de özen gösterme olarak algılanmalıdır. Diğer bir özellik, bakım hizmetlerinin sadece bakım veren ve bakım alan kişiler arasındaki ilişkiden (ikili veya bireysel) ziyade, politik bir yönünün de olduğudur. Bakım faaliyetlerinin, ikili veya bireysel yapıda olduğunun varsayılması, en başta sosyal ve politik olarak işlev görmesini kabul etmek demektir. Başka bir özellik, bakım faaliyetinin büyük ölçüde kültürel olarak tanımlandığ 1 için farklı kültürler arasında farklılık göstermesinin olağan olduğudur. Bu noktada belli ilkeler çevresinde sınırlar çizilerek tasarlanan bakım organizasyonun fayda getirmeyeceği savunulabilir. Son bir özellik ise bakımın devam eden bir süreç olmasıdır. Bu bağlamda bakım, günlük yaşam süreçlerinde yer alan canlı ve aktif bir olgudur ve hem bir uygulama hem de bir eğilimdir (Tronto, 1993, s. 103). Williams (2018, 557), Tronto'nun bakış açısını, "bakım etiği toplumu yaşatır ve onarır" ifadesiyle anlamlandırmıştır.

Bakım etiği savunucularına göre bakım, insanların temelde ilişkiler ağına karışmış sosyal varlıklar olduğunu önermesiyle başlar. Onlara göre bakım etiğinin çıkış noktası, insanların birbiriyle bağlantılı, birbirine bağımlı ve genellikle birbirleriyle eşit olmayan ilişkiler içinde var olan somut varlıklar olduğudur (Hankivsky, 2014, s. 253). Karş1lıklılık bağımlılık ve bağlılık gibi genel olarak ilişkilerin önemli özelliklerine değinmesinden dolayı bakım etiğinin dalları yalnızca yakın ilişkilere değil, her tür ilişki ve etkileşime kadar uzanmaktadır. Bakımın kendisi düzenli bir şekilde birlikte yaşama olasılığını tesis eden politik bir gerçekliktir. Başlangıçta özel ve mahrem yaşam alanlarına göre tasarlanan bakım etiği, bakım faaliyetlerinin çeşitliliğinden dolayı kapsamını genişletmiş, hayvanlara ve çevreye özen gösterme gibi pek çok ahlaki konu ve etik alan için de değerlendirilmeye alınmıştır. Bu nedenle bakım etiğinin, politik gerçeklik olduğu iddia edilebilir. 
Bakım etiği, alışılagelmiş etik biçimlerinden farklıdır. Onu farklı yapan en önemli karakteristik özellikleri; geleneksel ilkelerle ilgilenmemesi, bireysel faydaya odaklanmaması ve bakım sağlamanın toplumu oluşturan unsurlar olarak görülmesidir (Vosman, 2020, s. 19). Bakım etiğinin hızla dikkat çekmesinin bir nedeni, ilişkiselliğidir. Bu kavram, insanları genellikle asimetrik şekillerde karşılıklı olarak birbirine bağlı, savunmasız ve bağımlı olarak görür (Pettersen, 2011, s. 52). Bakım etiği literatürü incelendiğinde, feminist etik savunucularının ahlaki kararlar için başkalarına özen göstermenin gerekliliğini vurguladıkları görülmekte ve insanların sosyal varlıklar olduklarını, bu nedenle aralarında hep bir bağ kurduklarını ve bakım ilişkilerinin bu bağ etrafında konumlandığını savundukları söylenebilir.

Bakım etiği, bakımın sorumluluklarını ve uygulamalarını ahlaki bir çerçevede ele almayı önerir ve özellikle kadınların bakım verme pozisyonlarında yaygınlığının, kadınlığın doğal bir özelliğinden ziyade sosyal yapının neden olduğunu öne çıkarır. Bakım etiği, toplumsal cinsiyete dayalı kamu-özel ikilemine temelden meydan okuduğu için tarihsel olarak inşa edilmiş toplumsal cinsiyet normlarına, rollerine ve güç ilişkilerine meydan okur. Bu nedenle bakım etiği, normatif bir teori değil, feminist bir eleştirel teoridir (Robinson, 2011, s. 63). Bakım etiğinin politik bağlamda tanınması gereken bir olgu olduğu açıktır. Çünkü bakım etiği politik olarak düşünüldügünde sömürücü olmayan ve adil olan bakımın verilmesi ve alınmasıyla ilgili sorunlara çözümler arayacaktır.

\section{Bakım Etiği Bağlamında Kadın Yoksulluğunu Anlamak}

İnsanların bakım ile ilgili deneyimlerini aile ortamında edinmesinden dolay1, aile bakımı tüm bakım ilişkilerinin modellemesi olarak tanımlamak oldukça makuldür. Bakımın devletten, başta aileye daha sonra piyasaya veya kâr amacı gütmeyen bir organizasyona kaydırılmasına ilişkin mevcut fenomen oldukça yaygındır. Çünkü aile, genellikle doğal bir yapı olarak görünse bile belirli bir geçmişi olan sosyal bir kurumdur (Tronto, 2010, s. 161). Bakım işini özel hayatın bir parçası olarak düşünme eğilimi, bakım hizmetlerinin genellikle hanehalkı faaliyetleriyle ilişkilendirilmesine neden olmaktadır. Bakım işinin hane içerinde karşılanması gereken bir hizmet olması ve bu nedenle toplumda genellikle hane içinde; anne, kız kardeş, eş, ve kız evlat rollerinde olan kadınların bakım verenler olarak algılanması herkesçe kabul edilebilen bir gerçektir. Daha keskin bir ifade ile bakım işi, hala "kadın işis" olarak görülmektedir (Bauer \& Sousa-Poza, 2015, s. 10). 
Carol Gilligan ve diğer bakım etiği savunucularının bakım etiğini tanımlayan çalışmaları, özellikle kadın haklarına dikkat çekmek için sıklıkla alıntılanmaktadır. Gilligan, daha ilk andan itibaren bakım etiği kavramını cinsiyetçi bir argüman olarak görmediğini iddia etmiştir. Bakım etiği kavramının çıkış noktası kadınlara, ahlaki gelişim aşamalarında düşük statülerde yer verilmesi olsa da Gilligan'ın öncelikli amacı, bakım etiği argümanının, ahlaki alanın adaletini içerecek şekilde genişletilmesi gerektiğidir (Gilligan, 1993). Ancak bakım işi üzerine yapılan araştırmalarda, kadınların başrolde oldukları dikkat çekmektedir. Bu nedenle bakım, modern feminizm perspektifinde politik bir konu olarak ele alınmakta ve kadın emeği bağlamında tartışılmaktadır. 1960'ların sonunda ortaya çıkan biçimiyle feminizmin, bakım hizmetlerinin sözde "kadınsı" doğasına ve bununla bağlantılı olarak kadınların erkeklere tabi kılınmasına karşı bir isyan olduğu açıkça görülebilir (Sevenhuijsen, 2004, s. 5).

Tronto, bakımı; cinsiyet, sınıflar ve ırklar arasında eşit olmayan bir şekilde dağıtılmış bir sistem olarak araştırarak, bakımı bir güç konusu olarak açıkça gündeme getiren ilk bilim insanıdır. Onun görüşüne göre, bakım işinde kaynakların dağıtımıyla ilgili sorunlar nedeniyle taraflar arasında çatışmalar ortaya çıkmaktadır. Tronto'ya göre erkekler, ailesindekilerin veya başkalarının, bakım ihtiyaçlarını ihmal etmelerine rağmen bakım görevinden sorumlu tutulmamaktadırlar. Bu anlamda bakım işi, erkeklerin -ya da en azından bazı erkek gruplarının- ayrıcalıklı olarak bakım sorumluluklarını ihmal etmesini meşru kılacak şekilde cinsiyetlendirilmiştir. Tronto, ayrıcalıklı bir sınıf ve cinsiyet olarak bazı erkeklere atıfta bulunarak "ayrıcalıklı sorumsuzluk (privileged irresponsibility)" kavramının kullanılmasını önermektedir (Tronto, 1993, s. 121; Tronto, 2013, s. 58; Tronto, 2017, s. 40). Tronto, bakımın ahlaki yapısındaki toplumsal cinsiyet yanlılı̆̆ını yıkmaya yönelik bu görüşleri, Gilligan'ın bakım etiği yaklaşımına yeni bir soluk getirerek, farklılık katmıştır. Bununla ilgili olarak; "Gilligan'ın bakım etiğine ilişkin ifadesi dikkatimizi Kohlberg 'in teorisindeki bir toplumsal cinsiyet sinirına çekerken, Gilligan 'ın Kohlberg'in teorisinin temelde dışlayıcı mantı̆̆ını bozmadı̆̆ını iddia ediyorum. Sonuç olarak, Gilligan 'ın yazısının potansiyel olarak radikal etkileri körelmiştir ve onun teorisi, ahlakı kavramanın alternatif bir yolunu açıklamayı değil, toplumdaki kısmi ayrıcalığın bir açıklaması olarak işlev görmektedir "'(Tronto, 1993, s. 63) şeklindeki diğer bir görüşü, Gilligan'ın bakım etiği yaklaşımını eleştirdiğini göstermektedir. Gilligan'ın bakım etiği yaklaşımında, bakım işinin cinsiyete duyarlı olmayan yapısı yalnızca bir endişe kaynağı olmasına rağmen, 
bu endişe kaynağ 1 üzerine çıkan tartışmaların cinsiyete duyarlılık tartışmalarından ziyade, bakım etiğine ahlaki bir teori olarak odaklanılmasıyla ilgilidir. Oysa Tronto, özellikle bakım işindeki toplumsal cinsiyet farklılıklarını göz önüne alarak, bakım etiğini feminist bağlama oturtmaktadır.

Cinsiyete duyarlı ve sorumlu bakım uygulamalarını yansıtan politikalar için Tronto, bakım kurumlarını güçlendirme gerekliliğini savunmaktadır. Bu nedenle iyi bakım sağlamanın ne anlama geldiğine dair geliştirdiği açıklamalar, siyaset teorisi ve sosyal politika alanında önem kazanmaktadır. Bu açıklamalar, iyi bakım sağlamada aile ve piyasanın yetersiz kalması üzerinedir. Ek olarak iyi bir bakım uygulamasının; bakım amacı, güç ilişkilerinin tanınması ve bakımın bireylerin ihtiyaçlarını karşılamak için çoğulcu ve özel olarak düzenleme ihtiyacı olan unsurları, bakım etiğinin temel özelliklerini kullanmak suretiyle betimlenmektedir (Tronto, 2010). Ayrıca Tronto'yu, Gilligan'ın bakım etiği anlayışından ayıran bir diğer farklılık, bakım etiğine ilişkin sorunların çözümünü, politik sisteme dayandırmasıdır. Tronto, bakım etiğini, politik bir bakış açısıyla daha fazla analiz edilmesi gerektiğini vurgulayarak Gilligan'ın ötesine geçmektedir (Tronto, 2013). Böylece bakım alanında ihtiyaçları, katkıları ve beklentileri dikkate alan, bakım etiği bir siyasi süreç aracılığıyla kadınları yoksullaştıran durumun çözülmesi gerektiği savunulabilir.

Hem ücretli hem de ücretsiz bakım işi, özellikle çalışma dünyası için hayati öneme sahiptir. Küreselleşme, teknolojiye ayak uyduramama, işsizlik, düşük kaliteli istihdam ve iklim değişikliğinin yanı sıra çocuk, genç, hasta, engelli ve yaşl1lara yönelik bakım hizmetlerindeki eksiklikler nedeniyle ülkeler istihdam ve sosyal koruma sistemleri üzerinde artan baskılarla karşı karşıya kalmaktadır. Bununla birlikte cinsiyete dayalı iş bölümü ve kamu-özel alanlar arasındaki bölünme ile karakterize edilen bakımla ilgili sosyal yapı, yaşlanan nüfus ve kadınların toplumsal rollerinde ve isteklerinde meydana gelen dönüşümlerin etkisiyle değişime uğramaktadır. Bu nedenle özellikle merkez ülkelerde bir "bakım krizi” yaşandığı görülmektedir. Bakım hizmetleri sunumundaki eksiklikler, özellikle ülkelerin siyasi gündemlerinde giderek daha önemli bir konu olarak ortaya çıkmakta ve mücadele yöntemleri geliştirilmektedir. Mücadele yöntemlerinden biri, daha önce hanelerde gerçekleştirilen bazı görevlerin dışsallaştırılması ya da ev içi alandaki bakım işlerinin bir kısmını yapmak için ücretli yardım almak olarak tarif edilebilen "Küresel Bakım Zinciri (Global Care Chains)" yaklaşımıdır. Bu yaklaşım temel olarak, yoksul 
ülkelerdeki kadınların bakıcı olarak istihdam edilmesi yoluyla fakir ülkelerden zengin ülkelere aktarılmasıyla ilgilidir (Parreñas, 2012, s. 269). Bu aktarım, göçmen bakıcıların genellikle dünyanın dört bir yanında ücretli ve ücretsiz bakım çalışmalarına dayanan, ulus ötesi bakım hizmeti ile sonuçlanır (Hochschild, 2000, s. 131). Burada kadın göçmenler bakım emeği konusunda merkezi bir rol üstlenmekte ve bu işlerin, güvencesiz ve düşük ücretli olma eğilimi ile yüz yüzedirler (Orozco, 2009, s. 4-5).

Bakım ve refah düzenlemelerinde dikkat çeken işgücü piyasalarının cinsiyet analizi, kadın istihdamının genişlemesinin önünde bir engel olarak ücretsiz bakım sorumluluklarına işaret etmektedir (Orloff, 2002, s. 11). Ücretsiz bakım sorumluluklarını kadınlar öyle yüklenmişlerdir ki tarihsel ve kültürel bağlamda ve neredeyse her toplumda, bakım işinin kadınlara atfedildiği söylenebilir. Kadın emeğinin geleneksel görevi haline gelen ücretsiz bakım işinde harcadıkları günlük zaman ile ücretli bakım işinde harcadıkları günlük zaman ve erkeklerin ücretli ve ücretsiz bakım işinde harcadıkları günlük zamana ilişkin bilgileri incelemek üzere Grafik 1 oluşturulmuştur.

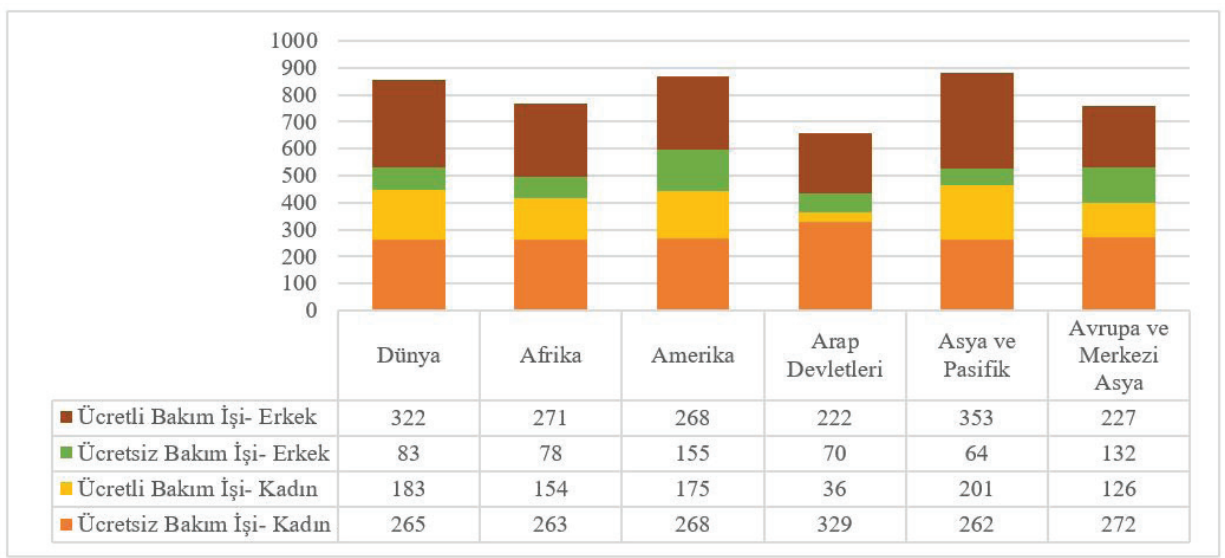

Grafik 1. Cinsiyet bazında ücretli ve ücretsiz bakım işine günlük harcanılan zaman, 2019 Kaynak: (International Labour Office, 2019a).

Grafik 1'e göre Dünya'da 3.2 kat, Arap Devletleri'nde 4.7 kat, Asya ve Pasifik'te 4.1 kat, Afrika'da 3.4 kat, Amerika'da 1.7 kat ve Avrupa ve Merkezi Asya'da 2.1 kat arasında değişmekte olan bir oran ile tüm bölgelerde kadınlar günlük ücretsiz bakım işlerinde erkeklere göre daha fazla zaman harcamaktadır. $\mathrm{Bu}$ arka planda, kadınların dünyanın her yerinde ücretsiz bakım işini günlük rutinlerinden biri haline getirdikleri, hatta bakım görevlerini bilinçli olarak benimsemedikleri, genellikle bakım hizmetlerinin üstlendikleri bir rol olduğu 
söylenebilir. Veriler 1şı̆̆ında erkeklerin bakım rolüne katılımının ikincil olma eğiliminde olduğu ve eğer bakım işine katılacaklarsa güvence şartı öne sürdüklerine ilişkin bir çıkarım yapılabilir. Çünkü Grafik 1'e göre erkekler yalnızca günlük ücretli bakım işinde hem dünyada hem de bölgelerde kadınlara göre daha fazla zaman harcamaktadır.

Kamu ve piyasa hizmetlerinin daha gelişmiş olduğu ülkelerin bulunduğu bölgelerde ücretsiz bakım işinin kadın ve erkek arasında eşit olarak paylaşıldığını düşünmek olağandır. Ancak Grafik 1'e göre geleneksel bakım sorumluluklarının dünyanın tüm bölgelerinde (gelişmiş ve/veya gelişmemiş) kadınlara atfedildiği söylenebilir. Buradan hareketle bakım işinin hala cinsiyete duyarlı bir şekilde dağılmadığı görülmektedir. Uluslararası Çalışma Örgütü (International Labour Organization -ILO), ücretsiz bakım işlerinde harcanan zamandaki cinsiyet farkının 2228'e kadar kapanmayacağını tahmin etmekte; başka bir ifade ile cinsiyet farkının kapatılmasının 209 yıl süreceğini iddia etmektedir (International Labour Office, 2019b, s. 13). Kadınlar ve erkekler arasındaki bu büyük eşitsizlik farkı, ücretsiz bakım işinin kapsamını ve dağılımını ele almada, geçmiş ve mevcut politikaların etkinliğini sorgulamaktadır.

Topluma dayalı sağlanan bakım hizmetleri, genellikle gayri resmi olarak kadınlar tarafından verilmekte olduğu söylenebilir. Kadınların birincil resmi olmayan bakıcı olmalarının ana nedenleri; evlatlık ilişkileri, birlikte ikamet etme ve coğrafi yakınlık olarak sıralanabilir. Bu durumda kadınlar tarafından sağlanan gayri resmi bakım hizmetleri, kadınlar için kaybedilen kariyer ve zaman ile duygusal çaba anlamlarına gelmektedir. Kadınların bakım işine ilişkin geleneksel sorumlulukları nedeniyle bağımsız karar alma hakları da kısıtlandığından bağımlı hale geldikleri söylenebilir. Kadınları ailenin özel alanı içinde sınırlandırmak, erkeklerin kamusal alanda tanınma ve güç kazanmalarını sağlayan bir unsurdur. Bu durum kadınların erkeklere bağımlılığını arttırır ve bağımsız olarak gelir ve servet elde etme firsatlarını önemli ölçüde kısıtlar (Parrott, 2001, s. 4). Gelir yoksulluğu ile ilişkilendirilebilecek bu durum ile mücadele etmek, başta kadınların ardından toplumun refah düzeyinin yükselmesi için büyük önem arz etmektedir.

Hükümet, bakıma ihtiyacı olanlara yeterli desteği sağlamadan evde kalmalarını teşvik ettiğinde özellikle hane içindeki kadınların iş yükü artabilir. Hükümetlerin bu tutumu, uzun vadeli sorunlara kısa vadeli çözümler bulmaktır. Çünkü teknoloji ve sağlık sistemlerinin gelişmesiyle özellikle hasta 
ve yaşlı bireyler, önceki dönemlere göre daha uzun süre hayatta kalmaktadır. Bu durumda bakım ihtiyaçları da küresel olarak artmaktadır. Ücretsiz bakım işlerinde kamu ve özel sektörün bıraktığ doldurması beklenmektedir. Bu durum aslında Hochschild'in "ikinci vardiya" terimiyle ölümsüzleşmiştir. İkinci vardiya, kadınların ev dışında çalışmaya başlamasından kısa bir süre sonra gerçekleşmesine rağmen terim olarak, Hochschild'in "The Second Shift (1989)" adlı kitabı yayınlanana kadar resmi bir biçimde ortaya çıkmamıştır. Kadınların maruz kaldığı ücretli ve ücretsiz çalışma sorumluluklarının ikili yükü olarak tanımlanan ikinci vardiya daha ayrıntılı bir tanım ile işgücündeki kadınların yalnızca "birinci vardiya"nın, başka bir ifadeyle günde sekiz saat ev dışında çalışmanın yüküyle değil, aynı zamanda "ikinci vardiyanın", başka bir ifadeyle günün geri kalanını hane içi bakım işiyle harcamasıdır. İkinci vardiyadan sonra Hochschild (1997), birinci ve ikinci vardiya arasındaki mücadele sonucunda ortaya çıkan duygusal emeği, üçüncü vardiya olarak tanımlar. Üçüncü vardiyanın tam bir tanımı olmamakla birlikte literatürde farklı konularda üçüncü vardiya hakkında çalışmalar yapılmıştır. Gallagher ve Delworth (1993), tarım dışı bir işte çalışarak ilk vardiyasını dolduran kadınların, ev içi ve bakım işinde ikinci vardiyalarını doldurduklarını ve ayrıca aile çiftliğini işleten bir üçüncü vardiyayı da günlük işlerine eklediklerini öne sürmektedirler. Gerstel (2000), kadınların erkeklere göre hane içinde daha fazla emek harcadığını iddia etmekte ve onların aile ve arkadaş ilişkilerini sürdürmek için harcadıkları emeği, yaşamlarında üçüncü bir vardiya olarak tanımlamaktadır. Wolf (2002) ise kadınların hayatındaki üçüncü bir vardiyanın "güzelleşme" olduğunu savunmuş ve kadınların iyi olma hali ile güzellik arasındaki ilişkiyi araştırmıştır. Haskin (2015)'de hane içi bakım yükünün erkekten çok kadınların omzunda olduğunu öne sürerek kadınların ailelerini ve sosyal çevrelerini koruduğunu savunmuştur. Ona göre bu koruyup kollama durumu, kadınların sevgi işine çok zaman ayırdığını, böylelikle birinci ve ikinci vardiyalarına ek olarak; sevgi, şefkat ve özen duygularını hane içinde ve dışında gösterdikleri için iş yüklerine fazlasını ekleyerek üçüncü bir vardiya yaratmaktadır.

Kadınların hane içi bakım yükünün artmasına küresel COVID-19 salgını da neden olmaktadır. Salgın, okulların ve birçok kayıtlı işletmenin kapanmasına neden olduğundan pek çok kadın, kendilerinin ve ailelerinin yaşam standardını korumak için yeterli para kazanma ihtiyacı ile ücretsiz bakım sorumluluklarındaki ani artışı dengelemek zorunda kalmaktadır (Ogando, Rogan, \& Moussie, 2021). 
Ayrıca salgın nedeniyle hemen hemen tüm ülkelerde, özellikle yaşlıların evde kalmalarına yönelik talimatlar gündeme gelmiştir. Bu durumda yaşlıların günlük temel ihtiyaçlarını karşılamak için aileleri, arkadaşları ve sosyal bakım görevlileri daha fazla bir bakım desteği üstlenmektedir. Bu desteğin çoğu da kadınların sorumluluğundadır. COVID-19 salgını, kadınların ekonomik ve sosyal güvencesizliğini ve ücretsiz bakım işine harcadıkları süreyi artırarak, kadınları sosyal ve kurumsal destekten mahrum bırakmaktadır (United Nations, 2020, s. 2).

Siyaset ve felsefe profesörü Nancy Fraser'ın toplumsal yeniden üretim olarak adlandırdığı; ekonominin, toplumun ve hane halkının temelinde yer alan yapıların ve kurumların işlemesini sağlayan düzenin, COVİD-19 salgını ile değiştiği görülmektedir. Toplumsal yeniden üretim, çocukları yetiştirmek ve yaşlıları desteklemekten sosyal örgütlenmeye ve daha büyük topluluklarda bağlantıları sürdürmeye kadar nesiller arası sosyal bağların yaratılması ve sürdürülmesi ile ilgilidir (Dugarova, 2020). Tarihsel olarak, toplumsal yeniden üretim süreçleri, erkeklerin sınırlı katılımı nedeniyle kadınların sorumluluğu olarak düşünülmüştür. Hem duygusal hem de maddi emekten oluşan ve çoğu zaman ücretsiz olarak gerçekleştirilen bakım işi, toplum için vazgeçilmezdir. $\mathrm{Bu}$ nedenle bakım konusunda meydana gelen sorunlar öncelikle toplumu olumsuz yönde etkilemektedir. Fraser $(2016,99)$, toplumsal yeniden üretime ilişkin çelişkilerin "bakım krizi” ile yorumlanabileceğini savunmaktadır. Salgın nedeniyle gündeme gelen sosyal mesafe ve karantina önlemleri ile insanlar arasındaki bağların askıya alındığı hatta bozulduğu söylenebilir. Bu durum ise toplumsal yeniden üretim üzerine baskı yapmakta ve bir anlamda bakım krizine neden olmaktadır. Çünkü COVID-19 salgını ekonomi ve sağlık ile yakından ilişkili olduğundan bakım kriziyle de karakterize edilebilen çok boyutlu bir olgu olarak açıklanabilir.

\section{Sonuç}

Bakım etiği, ahlaka uygun bir karar verilmesi gereken her durumda, özellikle katılım, uyumlu ilişkiler ve başkalarının ihtiyaçlarının önem kazandığı bakım işinde, etik bir yaklaşım oluşturur. Carol Gilligan bakım etiği kavramını geliştirdiğinde, ataerkilliğin kavramsal çerçevesine başarılı bir şekilde meydan okuyarak feminist anlayışı genişleten yeni bir paradigma yarattı. Aslında bu paradigma, yüzyıllardır erkeklik ve kadınlığın anlam ve işlevlerini tanımlayan 
hiyerarşik cinsiyet modelini devirmeye yöneliktir. Etik bakım anlayışı, insanlar arasındaki bakım sorumluluğu ve ilişkilerin ahlaki bir süreç içinde anlaşılması etrafında merkezlenir. Ayrıca feminist kuramcıların da ifade ettiği gibi bakım etiği, her şeyden önce bakım faaliyetlerini anlamlandırmanın yanı sıra yaşamın daha geniş bir alanını fark etmeleri için insanlara firsat sağlar (Tronto, 1998).

Doğurganlık oranının azalması ve hayatta kalma süresinin artmasından dolayı yaşlanma eksenli gerçekleşen demografik dönüşüm sonucunda yaşlı ebeveynlerin ihtiyaç duydukları bakım işini hanedeki kadının yüklenmesi küresel olarak sık karşılaşılan bir durumdur. Bununla birlikte çocuklara verilen bakım hizmetleri bir sevinç ve memnuniyet kaynağı olabilir ancak çocuk sahibi olmak aynı zamanda kadınların çalışma koşullarını da etkileyebilen bir faktördür. Hem gelişmekte olan hem de gelişmiş ülkelerdeki işgücü piyasası araştırmaları, annelerin, çocuk sahibi oldukları için sınırlı bir süre başka tür işleri yapma ve ekonomik olarak bağımsız olma becerilerini kısıtladığını ortaya koymakta hatta önemli bir ücret cezası ödediğini iddia etmektedir (Samman, ve diğerleri, 2016, s. 23). Genellikle kadınlara yüklenen yaşlı, çocuk, engelli ve diğer bakım ihtiyacı duyanlara verilen hane içindeki gayri resmi bakım hizmeti ücretsiz bakımı ifade etmektedir ve dünyanın tüm bölgelerinde erkekler, ücretli bakım işlerinde uzmanlaşırken, çoğunlukla ücretsiz bakım işine katılımları oldukça düşüktür. Oysa kadınlar, ücretsiz bakım işinin büyük kısmını yapmaktadır (Grafik 1). Bunlarla birlikte sosyal ve ekonomik krizlerden dolay1 tek bir gelirle haneyi geçindirmek, refah seviyesinde ciddi bir düşüşe sebep olabileceğinden, hanedeki kadın; ya yalnızca bakım verme işini yüklenerek ekonomik ve sosyal özgürlüğünden feragat etmiş olacak ya da ekonomik ve sosyal özgürlüğünü tercih edip, ücretli bir bakım vericisi ile anlaşacak veya her iki işi seçerek sırtına daha fazla yük bindirecektir ki tüm bu durumların hepsi hem maddi hem de manevi sonuçlar doğuracaktır. Meydana gelen bu maddi ve manevi sonuçlar aslında çok boyutlu yoksulluk olgusunun da doğmasına sebep olacaktır. Öyleyse kadınlara atfedilen geleneksel bakım rolünün kadınları yoksullaştırdığı söylenebilir. Böylece bakım etiği yaklaşımı kadın yoksulluğu ile mücadele stratejisi olarak düşünülebilir. Bu nedenle bakım etiğinin ahlaki felsefesine vurgu yaparak bakım hizmetlerini küresel sosyal politika ile bütünleştirmek için daha fazla çaba sarf edilmelidir. Bakım işlerinin önemsiz olduğu alg1sı, bakım sağlamakla uğraşan kişilere ödenen ücret ve maaşlar, bakımın bir şekilde "kadın işiı" olmasına yönelik varsayımları yıkmaya yönelik politikalar önerilmelidir. 
Genellikle ev ortamında sağlanan ücretsiz bakım işleri, kurumsal bir düzeyde ele alındığında "ekstra" işler olarak değerlendirilmektedir. Ev ortamının, en özenli bakım hizmetlerinin sağlandığı alanlar olduğu yadsınamaz bir gerçek olsa da bakım işlerinin kurumsal bir düzende "ekstra" işten "rutin" işlere dönüşmesi gerekmektedir. Bakımı insan yaşamının bir parçası olarak benimsemek, bir ömür boyu bakım alma ve bakım verme ilişkilerinin ve ara bağlantılarının varlığını kabul etmek, öncelikle kadınlar üzerindeki baskının azalmasını sağlayacak ve kadınların yoksullaşmasını önleyecek adımlar atılmasına öncü olacaktır. Son olarak bakım emeği; kadının, yardım kuruluşlarının ve göçmenlerin hizmetleriyle sınırlandırılmamalı, küresel bir bakım etiğinin inşa edilmesi temel bir görev olarak kabul edilmelidir.

Hakem Değerlendirmesi: Dış bağımsız.

Çıkar Çatışması: Yazar çıkar çatışması bildirmemiştir.

Finansal Destek: Yazar bu çalışma için finansal destek almadığını beyan etmiştir.

Peer-review: Externally peer-reviewed.

Conflict of Interest: The author has no conflict of interest to declare.

Grant Support: The author declared that this study has received no financial support.

\section{Kaynakça/References}

Bauer, J. M., ve Sousa-Poza, A. (2015). Impacts of Informal Caregiving on Caregiver Employment, Health, and Family. Journal of Population Ageing, 8(3), 113-145.

Burton, B. K., ve Dunn, C. P. (2013, October 1). Ethics of Care. Encyclopedia Britannica: https://www.britannica.com/topic/ethics-of-care

Dugarova, E. (2020). Unpaid Care Work in Times of the COVID-19 Crisis: Gendered Impacts, Emerging Evidence and Promising Policy Responses. Families in Development: Assessing Progress, Challenges and Emerging Issues. Focus on Modalities for IYF+30. UN Expert Group Meeting.

Fisher, B., ve Tronto, J. (1990). Towards a Feminist Theory of Care. E. E. Abel, \& M. Nelson (Eds.), Circles of Care. Albany, N.Y.: State University of New York Press.

Fraser, Nancy. (2016) Contradictions of Capital and Care. New Left Review, 100(99), 99-117.

Gallagher, E., ve Delworth, U. (1993). The Third Shift: Juggling Employment, Family, and the Farm. Journal of Rural Community Psychology, 12(2), 21-36.

Gerstel, N. (2000). The Third Shift: Gender and Care Work Outside the Home. Qualitative Sociology, 23(4), 467-483.

Gilligan, C. (1993). In a Different Voice: Psychological Theory and Women's Development. Cambridge: Harvard University Press.

Hankivsky, O. (2014). Rethinking Care Ethics: On the Promise and Potential of an Intersectional Analysis. American Political Science Review, 108, 252-264. 
Haskin, J. (2015). Third Shift Appearance Work: Experiences Of Career-Oriented Mothers. Wayne State University Dissertations.

Held, V. (2015). Care and Justice, Still. D. Engster, \& M. Hamington (Eds.), Care Ethics and Political Theory (pp. 19-36). Great Clarendon Street, Oxford: Oxford University Press.

Hochschild, A. (1989). The Second Shift. New York: Avon Books.

Hochschild, A. (1997). The Time Bind: When Work Becomes Home and Home Becomes Work. New York: Henry Hold \& Company, LLC.

Hochschild, A. (2000). Global Care Chains and Emotional Surplus Value. A. Giddens, ve W. Hutton (Eds.), Living with Global Capitalism (pp. 130-146). London: Jonathan Cape.

Holstein, M. (2010). Ethics and Old Age: The Second Generation. D. Dannefer, ve C. Phillipson (Eds.), The SAGE Handbook of Social Gerontology (pp. 630-640). SAGE.

Hugman, R. (1991). Power in Caring Professions. London: The Macmillan Press.

International Labour Office. (2019a, September 26). Advancing Social Justice, Promoting Decent Work. International Labour Office: https://www.ilo.org/global/about-the-ilo/ multimedia/maps-and-charts/enhanced/WCMS_721348/lang--en/index.htm

International Labour Office. (2019b). A Quantum Leap For Gender Equality : For A Better Future of Work for All. Geneva: ILO.

Kittay, E. F. (2011). The Ethics of Care, Dependence, and Disability. Ratio Juris, 24(1), 49-58.

Kohlberg, L. (1968). Early Education: A Cognitive-Developmental View. Wiley on behalf of the Society for Research in Child Development, 39(4), 1013-1062.

Kranak, J. (2019). Kantian Deontology. G. Matthews (Eds.), Introduction to Philosophy: Ethics (pp. 52-63). Rebus Community.

Lalor, K., \& Share, P. (2009). Understanding Social Care. K. Lalor, ve P. Share (Eds.), Applied Social Care: An Introduction for Students in Ireland (pp. 3-28). Gill \& Macmillan .

Moreira da Silva, J. (2019). Why You Should Care About Unpaid Care Work. OECD Development Matters.

Nguyen, M. T., Zavoretti, R., \& Tronto, J. (2017). Beyond the Global Care Chain: Boundaries, Institutions and Ethics of Care. Ethics and Social Welfare, 11(3), 199-212.

Noddings, N. (2013). Caring: A Relational Approach to Ethics and Moral Education. Berkeley and Los Angeles, California: University of California Press.

Ogando, A. C., Rogan, M., \& Moussie, R. (2021). Impacts of the Covid-19 Pandemic and Unpaid Care Work on Informal Workers' Livelihoods. International Labour Review.

Orloff, A. S. (2002). Women's Employment and Welfare Regimes: Globalization, ExportOrientation and Social Policy in Europe and North America. Geneva: Programme on Social Policy and Development, Paper No. 12. UNRISD . 
Orozco, A. P. (2009). Global Care Chains. United Nations, İnstraw.

Parks, J. A. (2003). No Place Like Home? Feminist Ethics and Home Health Care. Bloomington, Indiana: Indiana University Press.

Parreñas, R. S. (2012). The Reproductive Labour of Migrant Workers. Global Networks, $12(2), 269-275$.

Parrott, L. (2001). Social Work and Social Care (2. bs.). London: Routledge.

Pettersen, T. (2011). The Ethics of Care: Normative Structures and Empirical Implications. Health Care Analysis, 19, 51-64.

Razavi, S. (2007). The Political and Social Economy of Care in a Development Context: Conceptual Íssues, Research Questions and Policy Options. Geneva: Gender and Development Programme Paper No. 3 (UNRISD).

Robinson, F. (2011). The Ethics of Care: A Feminist Approach to Human Security. Philadelphia, Pennsylvania: Temple University Press.

Samman, E., Presler-Marshall, E., Jones, N., Bhatkal, T., Melamed, C., Stavropoulou, M., \& Wallace, J. (2016). Women's Work: Mothers, Children and the Global Childcare Crisis. London: Overseas Development Institute.

Sevenhuijsen, S. (2004). Citizenship and the Ethics of Care: Feminist Considerations on Justice, Morality and Politics. London \& New York: Routledge.

Tronto, J. C. (1987). Beyond Gender Difference to a Theory of Care. Signs, 12(4), 644663.

Tronto, J. C. (1993). Moral Boundaries: a Political Argument for an Ethic of Care. New York: Routledge.

Tronto, J. C. (1998). An Ethic of Care. Journal of the American Society on Aging, 22(3), $15-20$.

Tronto, J. C. (2010). Creating Caring Institutions: Politics, Plurality, and Purpose. Ethicsand Social Welfare, 4(2), 158-171.

Tronto, J. C. (2013). Caring Democracy: Markets, Equality and Justice. New York, NY: NYU Press.

Tronto, J. C. (2017). There is an Alternative: Homines Curans and the Limits of Neoliberalism. International Journal of Care and Caring, 1(1), 27-43.

United Nations. (2020). The impact of COVID-19 on women. New York: United Nations.

Vosman, F. (2020). The Disenchantment of Care Ethics A Critical Cartography. E. F. Vosman, A. Baart, ve J. Hoffman (Eds.), The Ethics of Care: the State of the Art (pp. 17-63). Leuven - Paris - Bristol, CT: Peeters Publishers.

Williams, F. (2018). Care: Intersections of Scales, Inequalities and Crises. Current Sociology, 66, 547-561.

Wolf, N. (2002). The Beauty Myth: How Images of Beauty are Used Against Women. New York: Harper Perennial. 
